\title{
Review: The Malay Peninsula
}

\section{Author(s): W. B.}

Review by: W. B.

Source: The Geographical Journal, Vol. 29, No. 3 (Mar., 1907), p. 335

Published by: geographicalj

Stable URL: http://www.jstor.org/stable/1776719

Accessed: 27-06-2016 03:02 UTC

Your use of the JSTOR archive indicates your acceptance of the Terms \& Conditions of Use, available at

http://about.jstor.org/terms

JSTOR is a not-for-profit service that helps scholars, researchers, and students discover, use, and build upon a wide range of content in a trusted digital archive. We use information technology and tools to increase productivity and facilitate new forms of scholarship. For more information about JSTOR, please contact support@jstor.org.

The Royal Geographical Society (with the Institute of British Geographers), Wiley are collaborating with JSTOR to digitize, preserve and extend access to The Geographical Journal 
and it will no doubt long remain an indispensable source of inspiration to all who desire to work out the relations between man and his environment within these islands.

\section{ASIA.}

\section{Tine Malay Peninsula.}

'British Malaya: An Account of the Origin and Progress of British Influence in Malaya.' By Sir Frank Swettenham, K.C.M.G., late Governor of the Straits Colony, ete. Loudon: John Lane, The Bodley Head.

The author of this instructive book, in his preface, remarks that though we have no special school for such training, yet Englishmen excel as administrators. He rightly connects this aptitude with our geographical position, which necessitates well-trained sailors, who, from early life, are accustomed to face the unexpected with equanimity. As he says, "it would be difficult to devise any responsibility, however onerous and unattractive, which a midshipman would not at once undertake, though it had no concern with sea or ship. . . . One may, however, question whether any one but a midshipman would have willingly embarked upon a voyage to discover the means of introducing order into the Malay States when that task was thrust upon the British Government in 1874."

The volume tells how this was done, and the story is as creditable to all concerned as it is gratifying to our national pride. For, to put it mildly, without encouragement from officials at home, and in spite of warning that if the limits of masterly inactivity were exceeded, the local officers would have to take all risk and bear all blame, yet they preferred responsibility to impotence. They boldly took the initiative in reform, and, when distrust was allayed, were completely supported by the Malays.

There are many States in the peninsula: some in the Straits Settlements (a crown colony), others under Siam, and those known as the Federated Malay States. The last group supplies the chief interest of Sir Frank Swettenham's book, whence the steps from chaos to prosperity may be traced. Not least among the factors of success were the Chinese, who worked the tin-mines. French and other European companies were formed for the purpose; "but it was the Chinese who began the work, who have continued it ever since, and whose efforts have succeeded in producing more than half of the world's tin supply. Their energy and enterprise have made the Malay States what they are to-day, and it would be impossible to overstate the obligation which the Malay Government and people are under to these hardworking, capable, and law.abiding aliens. . . . But the Chinese were not only miners ; ... as contractors, they constructed nearly all the Government buildings, most of the roads and bridges, railways, and waterworks. They brought all the capital into the country when Europeans feared to take the risk; they were the traders and shopkeepers; . . . and it is their work, the taxation of the luxuries they consume and of the pleasures they enjoy, which has provided something like nine-tenths of the revenue." This tribute to the race in Malaya may with advantage be considered, and its lesson be applied elsewhere.

The funds obtained from mining operations were used to darelop the country; roads, railways, irrigation, and jungle clearance were proceeded with, and cultivation followed. Para rubber was planted on a considerable scale, with results so profitable as to encourage young men with a taste for open-air life and adventure to seek their fortune in these States. The book is attractively got up, and the illustrations deserve special praise.

W. B. 